\title{
HYGIENIC ASSESSMENT OF PUBLIC HEALTH RISKS CAUSED BY FOOD CONTAMINATION WITH ORGANOCHLORINE PESTICIDES
}

\author{
Gorbachev DO $\bowtie$, Sazonova OV, Gavryushin MYu, Borodin LM
}

Samara State Medical University, Samara, Russia

\begin{abstract}
Accumulation of anthropogenic contaminants in food is one of the by-products of economic and other activities practiced by humankind. This study aimed to analyze the public health risks associated with ingestion of organochlorine pesticides $(\mathrm{HCH}, \mathrm{DDT})$ widely used in agriculture. The risk assessment was enabled by Nutri-prof software package; the data collected covered actual dietary patterns of 1798 people (823 men and 975 women) aged 18 to 65 . Assessment of the level of contamination of food with organochlorine pesticides relied on the results of analysis of 16510 food product samples belonging to various groups. Bread and bread products, vegetables and melons, potatoes, milk and dairy products were shown to be the source of $\mathrm{HCH}$ in the amounts causing the greatest noncancerogenic risk associated therewith. The list of products delivering the largest amounts of DDT into the body and thus posing the greatest non-cancerogenic risk associated therewith includes bread and bread products, vegetables and melons, meat and meat products, milk and dairy products. With the median DDT and $\mathrm{HCH}$ concentrations factored in, the highest joint cancerogenic risk level a person may be exposed to reaches the third range, which is acceptable for occupational groups. From the age of 45 , consumption of bread and bread products leads to the related endocrine system risks growing beyond background levels, and from 65 , these risks, considered negligible up to this age, become moderate. The results of this study support effectiveness of the sanitary and epidemiological food safety control system; the considered methodological approach to risk assessment allows making timely management decisions that account for the nature of work and dietary peculiarities.
\end{abstract}

Keywords: health risk, food, evolutionary risk model, organochlorine pesticides, DDT, $\mathrm{HCH}$

Author contribution: Concept and design of the study - Gorbachev DO, Sazonova OV. Data collection and processing — Gorbachev DO, Gavryushin MYu, Borodina LM. Text writing — Gorbachev DO, Sazonova OV. Editing — Gavryushin MYu, Borodina LM.

Compliance with ethical standards: Voluntary informed consent was obtained for each participant. The study was biomedical ethical and did not endanger the participants.

$\triangle$ Correspondence should be addressed: Dmitry O. Gorbachev

Chapaevskaya st., 89, Samara, 443099; d.o.gorbachev@samsmu.ru

Received: 16.03.2021 Accepted: 25.03.2021 Published online: 31.03.2021

DOI: $10.24075 /$ rbh.2021.006

\section{ГИГИЕНИЧЕСКАЯ ОЦЕНКА РИСКА ДЛЯ ЗДОРОВЬЯ НАСЕЛЕНИЯ, ОБУСЛОВЛЕННОГО КОНТАМИНАЦИЕЙ ПИЩЕВЫХ ПРОДУКТОВ ХЛОРОРГАНИЧЕСКИМИ ПЕСТИЦИДАМИ}

Д. О. Горбачев $џ$, О. В. Сазонова, М. Ю. Гаврюшин, Л. М. Бородина

Самарский государственный медицинский университет, г. Самара, Россия

\begin{abstract}
Хозяйственная деятельность человека приводит к накоплению в пищевых продуктах антропогенных контаминантов. Целью исследования был анализ риска для здоровья населения, обусловленный пероральным поступлением хлорорганических пестицидов (ГХЦГ, ДДТ), широко применявшихся в сельском хозяйстве. Оценка риска осуществлялась с учетом данных о фактическом питании 1798 человек (823 мужчин и 975 женщин) в возрасте от 18 до 65 лет с применением программного комплекса «Нутри-проф». Для оценки контаминации пищевых продуктов хлорорганическими пестицидами проанализировано 16510 проб различных групп пищевых продуктов. Наибольший неканцерогенный риск, обусловленный поступлением в организм с пищевыми продуктами ГХЦГ, обусловлен потреблением хлеба и хлебных продуктов, овощей и бахчевых, картофеля, молока и молочных продуктов, наибольший неканцерогенный риск при поступлении ддт с пищей обусловлен потреблением хлеба и хлебных продуктов, овощей и бахчевых, мяса и мясных продуктов, молока и молочных продуктов. Наивысший уровень суммарного индивидуального канцерогенного риска для дДТ и ГХЦГ с учетом медианной концентрации соответствует третьему диапазону и приемлем для профессиональных групп. Превышение фоновых значений риска для эндокринной системы при потреблении хлеба и хлебопродуктов наступает в 45 лет, переход с пренебрежимо малого уровня риска на уровень умеренного риска наступает в 65 лет. Полученные результаты указывают на эффективность системы санитарно-эпидемиологического надзора за безопасностью пищи, рассматриваемый методический подход к оценке рисков позволяет своевременно принимать управленческие решения с учетом характера трудовой деятельности и особенностей питания.
\end{abstract}

Ключевые слова: риск здоровью, пищевые продукты, эволюционная модель риска, хлорорганические пестициды, дДТ, гХЦГ

Вклад авторов: Концепция и дизайн исследования - Горбачев Д.О., Сазонова О.В. Сбор и обработка данных - Горбачев Д.О., Гаврюшин М.Ю. Бородина Л.М. Написание текста - Горбачев Д.О., Сазонова О.В. Редактирование - Гаврюшин М.Ю., Бородина Л.М.

Соблюдение этических стандартов: Добровольное информированное согласие было получено для каждого участника. Исследование соответствовало требованиям биомедицинской этики и не подвергало опасности участников.

$\triangle$ Для корреспонденции: Горбачев Дмитрий Олегович

ул. Чапаевская, д. 89, г. Самара, 443099; d.o.gorbachev@samsmu.ru

Статья получена: 16.03.2021 Статья принята к печати: 25.03.2021 Опубликована онлайн: 31.03.2021

DOI: $10.24075 /$ rbh.2021.006

Food safety plays one of the key parts in ensuring public health [1]. Contamination of food stock with anthropogenic pollutants caused by human economic activity can lead to the development of pathological conditions in people $[2,3,4]$. Organochlorine pesticides are among the anthropogenic contaminants polluting food stock in the context of agricultural activities [5].
DDT (dichlorodiphenyltrichloromethylmethane) and $\mathrm{HCH}$ (hexachlorocyclohexane), both organochlorine pesticides, are insect control chemicals applied to seasonal and perennial crops [6]. These contaminants, which are taken by people with food, have potential teratogenic, carcinogenic, hormonal, neurological and immunological properties [7, 8, 9]. 
Food contamination control, as well as the analysis of health risks associated with ingestion of foreign agents, are the key tools supporting and promoting food security in the Russian Federation. They are also an integral part of the country's demographic policy [10].

This study aimed to analyze the public health risks associated with ingestion of organochlorine pesticides, with the results of this analysis enabling evaluation of the effectiveness of sanitary and epidemiological control operations in the Samara region and generation of the new approaches to risk assessment relying on evolutionary models.

\section{MATERIALS AND METHODS}

The assessment of dietary patterns peculiar to various occupational categories involved collecting data from the participating residents of Samara region, the collection relying on surveys powered by Nutri-prof software [11]. The participants of the study were 1798 people aged 18 to 65 years, 823 male and 975 female. The surveys allowed learning their food habits structured by the main food groups. The occupational categories the participants were grouped by reflected nature of their work and gender specifics; they were "education", "healthcare", "industrial production", "office", "agriculture". Food contamination with organochlorine pesticides was determined in the laboratory of the Samara Region Center for Hygiene and Epidemiology, the gas-liquid chromatography tests aimed at identifying concentrations of such compounds as $\mathrm{HCH}$ and DDT. A total of 16510 samples were analyzed. Automated assessment of carcinogenic and non-carcinogenic risks, which factored in exposure of the occupational groups to organochlorine compounds, relied on the Food Contamination Database. The assessment considered combined exposure to the contaminants, their median and 90th percentile concentrations.

\section{RESULTS}

Organochlorine pesticides $(\mathrm{HCH}$, DDT) were found in bread and bread products, vegetable oil and other fats/oils, milk and dairy products, meat and meat products, eggs, fish and fish products, sugar and sweets/pastries, fruits and berries, vegetables and melons, and potatoes. Their median and $90^{\text {th }}$ percentile concentrations were established (Table 1).

Analysis of the $\mathrm{HCH}$ content in food showed that eggs, vegetable oil and other fats have the maximum median concentrations, the lowest values were registered in such plant products as vegetables, fruits and potatoes (in the range of
$0.0163-0.0032 \mathrm{mg} / \mathrm{kg}$ ). As for DDT, the highest concentrations thereof were found in meat and meat products, and vegetable oil and other fats had it in concentrations ranging from 0.0143 to $0.0044 \mathrm{mg} / \mathrm{kg}$.

The subsequent assessment of exposure and hazard ratios associated with ingestion of organochlorine contaminants factored in the specifics of their consumption in various occupational groups, these specifics reported by the participants when describing their actual dietary patterns.

The maximum non-carcinogenic risk associated with taking $\mathrm{HCH}$ with food was 0.01 (median), and with the $90^{\text {th }}$ percentile accounted for -0.096 . Women falling into the "industrial production" category were specifically exposed to this risk due to consumption of bread and bread products, vegetables and melons, potatoes, milk and dairy products.

The maximum non-carcinogenic risk associated with ingestion of DDT with food (median) was established in the "agriculture" group among males, with the value being 0.24 , and among females of the "industrial production" group, with the same value. By the 90th percentile, females of the "industrial production" group ran the highest risk (0.66). The risks arose from consumption of bread and grain products, vegetables and melons and gourds, meat and meat products, milk and dairy products contaminated with DDT.

The joint hazard index $\left(\sum \mathrm{HI}\right)$ describing concurrent and long-term exposure to (intake of) $\mathrm{HCH}$ and DDT showed that females of the "industrial production" group ran the highest risk (Table 2).

According to the "Guidelines for assessing public health risks associated with exposure to environment pollutants" ( $R$ 2.1.10.1920-04), liver and the endocrine system are the organ and system critically affected upon exposure to DDT, therefore, females of the "industrial production" group run the highest risk of negative consequences from oral contact with organochlorine contaminants.

Accounting for the exposure and the slope factors (SFo) of the studied contaminants, we evaluated the risk of carcinogenic effects they may have on representatives of the various occupational groups. The highest level of individual and population carcinogenic risks associated with median concentration for DDT was established for the male part of the "agriculture" occupational group $\left(4.1 \times 10^{-5}\right.$ and 0.41 cases per 10,000 people, respectively). Same group ran the highest risk of cancer associated with DDT ingestion (0.000184 and 1.84 per 10000 population). Females in the "industrial production" group had the highest DDT-induced individual and population carcinogenic risk level, which amounted to 0.00011 and 1.11 cases, respectively. As for $\mathrm{HCH}$, in this occupational group the

Table 1. Median and $90^{\text {th }}$ percentile content of organochlorine pesticides in food $(\mathrm{mg} / \mathrm{kg}$ )

\begin{tabular}{|c|c|c|c|c|}
\hline \multirow{2}{*}{ Food groups } & \multicolumn{2}{|c|}{$\mathrm{HCH}$} & \multicolumn{2}{|c|}{ DDT } \\
\hline & $\mathrm{Me}$ & 90 & $\mathrm{Me}$ & 90 \\
\hline Bread and bread products & 0.0051 & 0.0543 & 0.0053 & 0.0065 \\
\hline Vegetable oil and other oils/fats & 0.0147 & 0.0296 & 0.0095 & 0.0276 \\
\hline Milk and dairy products & 0.0061 & 0.0072 & 0.0049 & 0.0054 \\
\hline Meat and meat products & 0.0047 & 0.0188 & 0.0143 & 0.0362 \\
\hline Egg & 0.0162 & 0.0163 & 0.005 & 0.005 \\
\hline Fish and fish products & 0.0046 & 0.0073 & 0.0052 & 0.0114 \\
\hline Sugar and sweets/pastry & 0.0049 & 0.0072 & 0.0048 & 0.0078 \\
\hline Fruits and berries & 0.0042 & 0.0049 & 0.0051 & 0.006 \\
\hline Vegetables and melons & 0.0035 & 0.1048 & 0.0047 & 0.0248 \\
\hline Potatoes & 0.0032 & 0.0735 & 0.0044 & 0.0334 \\
\hline
\end{tabular}


Table 2. Total hazard indices in occupational groups, median and $90^{\text {th }}$ percentile $\mathrm{HCH}$ and DDT concentrations

\begin{tabular}{|l|c|c|c|c|}
\hline \multirow{3}{*}{ Occupational group } & \multicolumn{2}{|c|}{$\sum \mathrm{HI}$} & \multicolumn{2}{c|}{$\sum \mathrm{HI}$} \\
\cline { 2 - 5 } & \multicolumn{2}{|c|}{$\mathrm{Me}$} & female & male \\
\cline { 2 - 5 } & female & male & 0.68 & 0.5 \\
\hline "education" & 0.23 & 0.198 & 0.51 & 0.48 \\
\hline "health care" & 0.182 & 0.176 & 0.756 & 0.693 \\
\hline "industrial production" & 0.25 & 0.239 & 0.456 & 0.428 \\
\hline "office" & 0.167 & 0.156 & 0.6 & 0.71 \\
\hline "agriculture" & 0.2209 & 0.241 & \\
\hline
\end{tabular}

individual risk arising from ingestion of this chemical was at the level of 0.00147 , and the population risk amounted to 17.4 cases per 10000 people.

With the median DDT and $\mathrm{HCH}$ concentrations factored in, the total individual and population carcinogenic risk arising from the combined effects of DDT and $\mathrm{HCH}$ in all studied occupational groups falls within the third range (individual risk throughout life ranging from $1 \times 10^{-4}$ to $1 \times 10^{-3}$ ), which is acceptable for occupational groups and unacceptable for the general population. With the 90th percentile DDT and $\mathrm{HCH}$ concentrations factored in, the total individual carcinogenic risk associated with these chemicals affecting the body jointly in all studied occupational groups falls within the fourth range, which is considered unacceptable (individual risk throughout life $\geq 0.001$ ) neither for occupational groups nor for the general population and requires urgent mitigation measures on the organizational level.

Assessment of the contribution of individual food groups to the total risk load revealed that consumption of bread and bread products aggravates the cumulative risk associated with exposure to organochlorine pesticides. Using the paired relationships reflecting the influence of alimentary factors shaped by contamination of this food group with organochlorine pesticides we developed evolutionary models showing health risks accumulation and accounting for damage to the most vulnerable organs and systems. At the given level of risk and considering life-long and ever growing exposure to contaminants, health disorders are likely to develop in the case investigated. Thus, it is possible to model the likelihood of disease development for the given contaminant exposure values and make management decisions aimed at prevention. According to the literature, $\mathrm{HCH}$ and DDT have a negative effect on the endocrine system. Relying on the median pesticide concentrations, we built an evolutionary model of non-carcinogenic risk for the endocrine system associated with consumption of bread and bread products, which showed that, starting from the age of 45 , the evolutionary risk grows beyond background levels, and from 65, these risks, considered negligible up to this age, become moderate (Figure).

\section{DISCUSSION}

Most organochlorine pesticides, including $\mathrm{HCH}$ and DDT, are persistent organic pollutants contaminating environment in general and food in particular. These chemicals cause the risk of development of non-carcinogenic and carcinogenic diseases [12,13].

The Russian Federation food security concept relies on the multi-stage system for assessing risks associated with food contamination. The methodological approaches to modeling the evolution of risk that are currently practiced in our country underlie the methodology for chemicals-related public health risks assessment and food (goods) safety appraisal, which is recommended by the Eurasian Economic Commission [14]. Both in our country and other countries of the Eurasian Economic Union (EAEU), there functions a multi-level legislative system regulating the health risks assessment procedure, the list of such risks including those arising from food contamination $[15,16]$.

This study has shown that in the Samara region, the state sanitary and epidemiological control system ensures food safety through permitting sale of food containing permissible levels of organochlorine contaminants. Nevertheless, the analysis of risk associated with contamination of food stock with these compounds revealed the most vulnerable occupational groups, those bearing the highest risk load, including risks arising from the consumption of contaminated food with high values of pesticide content $\left(90^{\text {th }}\right.$ percentile).

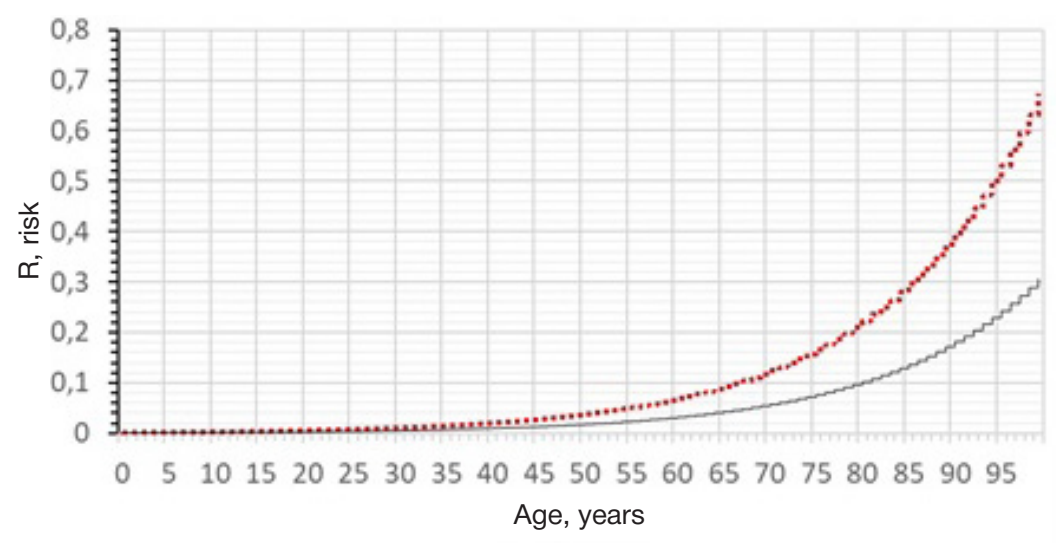

....... Evolutionary risk (1)

Evolutionary risk (background)

Fig. Evolutionary model of non-carcinogenic risk from endocrine system arising from ingestion of contaminants with bread, bread products (median concentrations) 
We analyzed the actual dietary patterns of various population groups (although, from the methodological viewpoint, risk assessments typically rely on Rosstat data reflecting average annual consumption) and received data on exposure to organochlorine pesticides in specific occupational groups. The maximum carcinogenic risk associated with ingestion of DDT and $\mathrm{HCH}$ was established in the "agriculture" group among males and in the "industrial production" group among females. The maximum carcinogenic risk associated with exposure to DDT and $\mathrm{HCH}$ was established for females of the "industrial production" group. In all occupational groups, the level of carcinogenic risk, with the growth of median concentration factored in, falls in the third range. We have built a noncarcinogenic risk evolutionary model revealing the development of endocrine system disorders; this model shows that the key contributors to aggravation of such disorders are bread and bread products, and that starting from the age of 45, the evolutionary risk grows beyond background levels, and from 65, these risks, considered negligible up to this age, become moderate. The suggested herein methodological approach to risk assessment factors in dietary specifics and structure, as well as food habits, exposure to contaminants depending on the pesticide ingestion scenario, which can be based on median concentration values or maximum concentrations, the latter a pessimistic scenario. With this approach, risk analysis and subsequent management decisions are made in a more differentiated manner, which ultimately affects the effectiveness and appropriateness of preventive measures.

\section{CONCLUSIONS}

Thus, the hygienic assessment of public health risks associated with contamination of food with organochlorine pesticides has shown that the current sanitary and epidemiological control practices adopted in the Samara region to ensure food safety are effective and aimed at preserving and improving health of the population. The methodological approach to evolutionary risk models, which relies on software and factors in the actual dietary patterns found in various occupational groups, allows full assessment of nutritional risks, identification of the most vulnerable occupational groups and timely management decisions aimed at mitigation of the factors that shape negative health impact in specific populations.

\section{References}

1. Frolova JA, Tafeeva EA, Frolov DN, Bocharov EP. Alimentarydependent diseases of the population and the hygienic characteristic of the factors of the risk of their development in the territory of the republic of Tatarstan. Hygiene and sanitation. 2018; 97(5): 470-473.

2. Sadeghi $F$, Nasseri $S$, Yunesian $M$, Nabizadeh $R$, Mosaferi $M$, Mesdaghinia A. Carcinogenic and non-carcinogenic risk assessments of arsenic contamination in drinking water of Ardabil city in the Northwest of Iran. J. Environ. Sci. Health A Tox. Hazard. Subst. Environ. 2018; 53 (5): 421-429. DOI: 10.1080/10934529.2017.1410421

3. Tutelyan VA, Nikityuk DB, Khotimchenko SA. Normative base for food quality and safety assessment. Russian Journal of Rehabilitation Medicine. 2017; (2): 74-120.

4. Klepikov OV, Khatuaev RO, Istomin AV, Rumyantseva LA. Regional features of food standards and health risks associated with chemical contamination of food. Hygiene and sanitation. 2016; 95 (11): 1086-1091.

5. Mamontov AA, Tarasova EN, Mamontova EA. Persistent organic pollutants in soils of the southern Baikal. Environmental chemistry. 2018; 27(2): 65-75

6. Galiulin RV, Galiulina RA, Horobryh RR. Contamination of water bodies with residues of organochlorine insecticides DDT and $\mathrm{HCH}$. Water treatment. Water purification. Water supply. 2014; 1 (73): 68-70.

7. Chashchin VP, Kovshov AA, Gudkov AB, Morgunov BA. Socioeconomic and behavioral risk factors of disabilities among the indigenous population in the far north. Human ecology. 2016; (6): $3-8$.

8. Tanabe S, Subramanian A. Bioindicators of POPs: monitoring in developing countries. Kyoto, Japan: Kyoto University Press;
Melbourne: Trans Pacific Press, 2006; 190 p.

9. Tsygankov VYu, Yarygina MV, Lukyanova ON, Boyarova MD, Erofeeva NI, Gamova SV, Gumovskiy AN, Kiku PF. Trace concentrations of organochlorine compounds in biological liquids of the Russian Far East residents. Human ecology. 2019; (1) 15-19.

10. Popova AYu. Risk analysis as a strategic sphere in providing food products safety Health Risk Analysis. 2018; (4): 4-12.

11. Baturin AK, Martinchik AN, Gorbachev DO, Sazonova OV, Mihajlov NA. "A software package for the assessment of dietary intake "Nutri-prof " Certificate of registration of the computer program RU 2018616124, 23.05.2018. Application № 2018613172 от 03.04.2018.

12. Fiedler H, Kallenborn R, Boer JD \& Sydnes LK. (2019). The Stockholm Convention: A Tool for the Global Regulation of Persistent Organic Pollutants. Chemistry International. 2019 41(2), 4-11. DOI: 10.1515/ci-2019-0202.

13. Upadhayay J, Rana M, Juyal V, Bisht SS, Joshi R. Impact of pesticide exposure and associated health effects. In: Pesticides in crop production: physiological and biochemical action. Ed. Srivastava P.K. 2020; Chapter 5; 69 - 88 p.

14. Zaitseva NV. Analysis of population health risks in the Russian Federation caused by food products contamination. Health Risk Analysis. 2018; (4): 13-23.

15. Gorbachev DO, Sazonova OV, Borodina LM, Gavryushin MY Analyzing health risks for employable population caused by food products contamination (experience gained in Samara region). Health Risk Analysis. 2019; (3): 42-49.

16. Nurgalieva MT, Smagulov AK, Iskakova ZhA. The issues of quality and safety control of food products in the framework of EU and EEU. Science and world. 2016; 3(31): 86-91.

\section{Литература}

1. Фролова О. А., Тафеева Е. А., Фролов Д. Н., Бочаров Е. П. Алиментарно-зависимые заболевания населения и гигиеническая характеристика факторов риска их развития на территории Республики Татарстан. Гигиена и санитария. 2018; 97(5): 470-473.

2. Sadeghi F, Nasseri S, Yunesian M, Nabizadeh R, Mosaferi M,

Mesdaghinia A. Carcinogenic and non-carcinogenic risk assessments of arsenic contamination in drinking water of Ardabil city in the Northwest of Iran. J. Environ. Sci. Health A Tox. Hazard. Subst. Environ. 2018; 53 (5): 421-429. DOI: 10.1080/10934529.2017.1410421

3. Тутельян В. А., Никитюк Д. Б., Хотимченко С. А. Нормативная 
база оценки качества и безопасности пищи. Российский журнал восстановительной медицины. 2017; (2): 74-120.

4. Клепиков О. В., Хатуаев Р. О., Истомин А. В., Румянцева Л. А. Региональные особенности питания населения и риск для здоровья, связанный с химической контаминацией пищевых продуктов. Гигиена и санитария. 2016; 95 (11): 1086-1091.

5. Мамонтов А. А., Тарасова Е. Н., Мамонтова Е. А. Стойкие органические загрязнители в почвах южного Байкала. Экологическая химия. 2018; 27(2): 65-75.

6. Галиулин Р. В., Галиулина Р. А., Хоробрых Р. Р. Загрязнение водных объектов остатками хлорорганических инсектицидов ДДТ И ГХЦГ. Водоочистка. Водоподготовка. Водоснабжение. 2014; 1 (73): 68-70.

7. Чащин В. П., Ковшов А. А., Гудков А. Б., Моргунов Б. А Социально-экономические и поведенческие факторы риска нарушений здоровья среди коренного населения Крайнего Севера. Экология человека. 2016; (6): 3-8.

8. Tanabe S, Subramanian A. Bioindicators of POPs: monitoring in developing countries. Kyoto, Japan: Kyoto University Press; Melbourne: Trans Pacific Press, 2006; 190 p.

9. ЦЦыганков В. Ю., Ярыгина М. В., Лукьянова О. Н., Боярова М. Д., Ерофеева Н. И., Гамова С. В., Гумовский А. Н., Кику П. Ф. Следовые концентрации хлорорганических соединений в биологических жидкостях жителей юга Дальнего Востока России. Экология человека. 2019; (1): 15-19.

10. Попова А. Ю. Анализ риска - стратегическое направление обеспечения безопасности пищевых продуктов. Анализ риска здоровью. 2018; (4): 4-12.

11. Батурин А. К., Мартинчик А. Н., Горбачев Д. О., Сазонова О. В., Михайлов Н. А. "Программный комплекс по оценке фактического питания "Нутри-проф" Свидетельство о регистрации программы для ЭBM RU 2018616124, 23.05.2018. Заявка № 2018613172 от 03.04.2018.

12. Fiedler H, Kallenborn R, Boer JD \& Sydnes LK. (2019). The Stockholm Convention: A Tool for the Global Regulation of Persistent Organic Pollutants. Chemistry International. 2019 41(2), 4-11. DOI: 10.1515/ci-2019-0202.

13. Upadhayay J, Rana M, Juyal V, Bisht SS, Joshi R. Impact of pesticide exposure and associated health effects. In: Pesticides in crop production: physiological and biochemical action. Ed. Srivastava PK. 2020; Chapter 5: 69 - 88

14. Зайцева Н. В. Анализ рисков для здоровья населения Российской Федерации, обусловленных загрязнением пищевых продуктов. Анализ риска здоровью. 2018; (4): 13-23.

15. Горбачев Д. О., Сазонова О. В., Бородина Л. М., Гаврюшин М. Ю. Анализ риска здоровью трудоспособного населения, обусловленного контаминацией пищевых продуктов (опыт Самарской области). Анализ риска здоровью. 2019; (3): 42-49.

16. Нургалиева М. Т., Смагулов А. К., Искакова Ж. А. Вопрось регулирования качества и безопасности пищевой продукции в рамках Европейского и Евразийского экономического союза. Наука и Мир. 2016; 3(31): 86-91. 